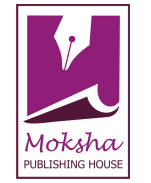

\author{
Research Article \\ www.ijrap.net
}

\title{
CHAKRAMARDA TAILA PREPARATION AND PHYSICO-CHEMICAL EVALUATION
}

Anoma Geethani Samarawickrama ${ }^{1 *}$, Ajantha ${ }^{2}$, Chethana kumari D ${ }^{1}$

${ }^{1}$ PG Scholar, Department of Roga Nidana, Sri Dharmasthala Manjunatheshwara College of Ayurveda and

Hospital, Hassan, Karnataka, India

${ }^{2}$ Associate Professor, Department of Roga Nidana, Sri Dharmasthala Manjunatheshwara College of Ayurveda and Hospital, Hassan, Karnataka, India

Received on: 10/01/17 Revised on: 13/02/17 Accepted on: 13/03/17

\author{
*Corresponding author \\ E-mail: samarawickrama381@gmail.com
}

DOI: $10.7897 / 2277-4343.08259$

\begin{abstract}
Chakramarda (Cassia tora Linn) is a well-known medicinal plant with krimighna, kandughna and dadrughna activity. It is commonly indicated in kasa, gulma and krimi. Chakramarda taila is an anubhoota yoga used as external application in the management of Dadru kushta (Dermatophytosis). Since it is an anubhoota yoga, knowledge of its preparation and analysis of physical parameters and chemical parameters, help to evaluate, standardize and achieve quality control. Analytical parameters are important tools in establishing identity, purity and strength of finished product. Under analytical study, Physical parameters like Specific gravity, Viscosity, refractive index are dealt and under chemical parameters Acid value, Iodine value, Saponification value, Unsaponifiable matter, Peroxide value, HPTLC of Chakramarda taila is studied.
\end{abstract}

Keywords: Chakramarda, Kushtaghna, anubhoota yoga, Sneha kalpana, Analytical parameter

\section{INTRODUCTION}

Chakramarda Taila is an anuboota yoga. The ingredients of Chakramarda taila are Chakramarda seeds (Cassia tora. Linn) and Tila taila (Sesamum indicum). Chakramarda seeds (Cassia tora) are well known for their Kushtaghna, Kandughna, and Dadrughna $^{1}$ effect. Seeds of Chakramarda (Cassia tora) contain Chrysophanol and Chrysophanic $\mathrm{acid}^{2}$ and thereby constitute a valuable remedy in skin diseases especially in Ringworm. Taila Kalpana is a pharmaceutical process dealt under the Sneha Kalpana $^{3}$. Taila play an important role in therapeutics and are advised both external \& internal purposes ${ }^{4}$. For globalization of Ayurveda drug standardization is very necessary. Hence analytical parameters are essential as a measure of quality control and standardization of finished product. Analytical parameters are important tools in establishing identity, purity and strength of finished product. Without analytical study, the drug study is incomplete. Analytical study of a product provides standards to judge its quality.

Aim and objectives of the study

1. Preparation of Chakramarda taila.

2. Evaluation of Chakramarda taila for organoleptic and physico-chemical parameters.
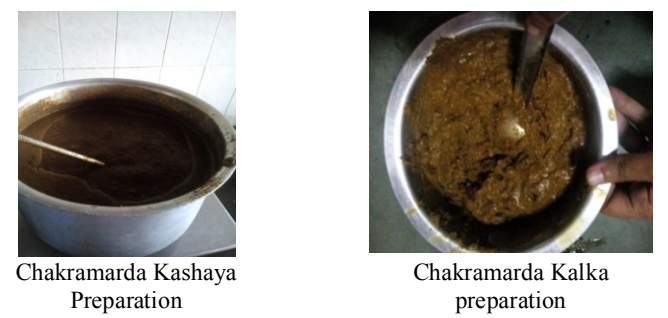

\section{MATERIAL AND METHODS}

Among the ingredients of Chakramarda taila, Chakramarda seeds were collected from Mysuru and Tila taila from Hassan. The authentication of raw drugs was done in the Department of Dravyaguna and Chakramarda taila was prepared in the Department of Rasa shastra and Bhaishajya kalpana of Sri Dharmasthala Manjunatheshwara College of Ayurveda and Hospital, Hassan.

\section{Method of preparation}

Chakramarda taila is prepared based on the samanya taila paka vidhi ${ }^{5}$. Seeds of Chakramarda are taken cleaned, dried and a coarse powder was prepared. To prepare Kashaya $5 \mathrm{~kg}$ of Chakramarda seeds (Cassia tora Linn) is made into coarse powder to which 40 liters of water is added and kept on heating device. Heating was continued on mandagni till it reduced to 1/4th. On filtration ten liters of Kashaya is got. This 10 liters kashaya with Chakramarda kalka $(625 \mathrm{~g})$ and Tila taila (Sesamum indicum) $(2500 \mathrm{ml})$ was subjected to sneha paka by heating on mandagni, till the taila paka siddha lakshanas were obtained. Then filtered in warm condition. Later taila was bottled and labeled. Steps involved in the preparation of Chakramarda taila are shown in Figure 1.
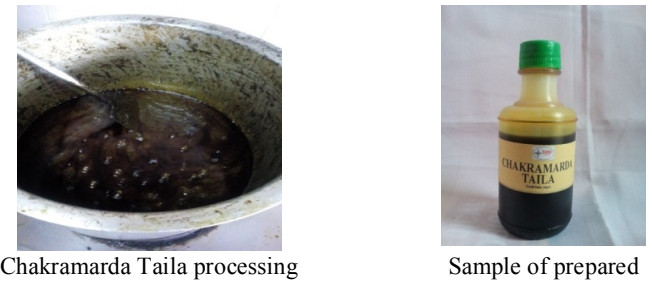

Sample of prepared Chakramarda taila

Figure 1: Steps involved preparation of Chakramarda taila 


\section{Analytical Study}

The present study, analytical evaluation of Chakramarda taila was carried out to determine the physico-chemical parameters. The study was carried out at S.D.M. Centre for Research in Ayurveda and Allied Sciences, Udupi. Chakramarda taila formulation was analyzed for following parameters as per the references available in protocol for testing published by CCRAS .

1. Organoleptic characteristics - using sensory organs.

2. Physical parameters -Refractive index, specific gravity, viscosity.

3. Chemical parameters- Acid value, Iodine value, Saponification value, Unsaponifiable matter, Peroxide value.

4. HPTLC analysis using- Toluene: Ethyl Acetate (9:1) as Solvent system

\section{OBSERVATION AND RESULTS}

The organoleptic characters of Chakramarda taila are given in Table 1.

The observations of physical parameters of Chakramarda taila are given in Table 2.

The observations of chemical parameters are mentioned in Table 3.
Table 1: Organoleptic characters of Chakramarda taila

\begin{tabular}{|c|c|}
\hline Parameters & Chakramarda taila \\
\hline Color & Green \\
\hline Odour & Characteristic \\
\hline Taste & Acrid \\
\hline
\end{tabular}

Table 2: Physical parameters for Chakramarda taila

\begin{tabular}{|c|c|}
\hline Parameters & Chakramarda taila \\
\hline Refractive index & 1.47032 \\
\hline Specific gravity & 0.9385 \\
\hline Viscosity & 58.08 \\
\hline
\end{tabular}

Table 3: Chemical parameters for Chakramarda taila

\begin{tabular}{|c|c|}
\hline Parameters & Chakramarda taila \\
\hline Acid value & 1.04 \\
\hline Saponification value & 162.30 \\
\hline Iodine value & 10.73 \\
\hline Peroxide value & 1.58 \\
\hline Unsaponifiable matter & 1.82 \\
\hline
\end{tabular}

The HPTLC shows 15 different Rf values in total, among which when observed under $254 \mathrm{~nm}$ (Short UV) there were 9 bands observed, under 366nm (Long UV) 7 bands were observed and following derivatization with vanillin sulphuric acid 9 bands were evident (Figure 2, Table 4).

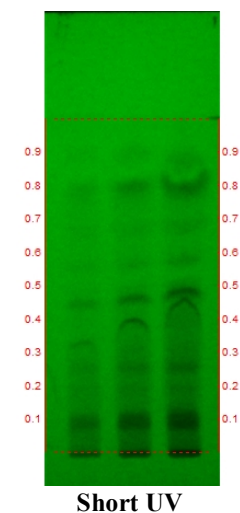

Short UV

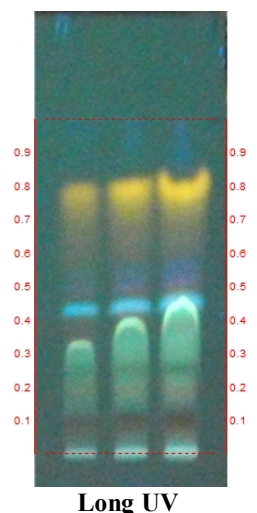

Long UV

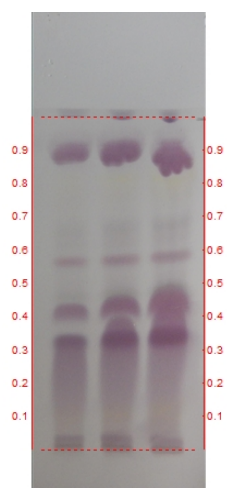

Under white light (after derivatisation)

Figure 2: HPTLC photo documentation of chloroform extract of Chakramarda taila

Track 1-Chakramarda taila $-4 \mu$, Track 2-Chakramarda taila $-8 \mu$, Track 3-Chakramarda taila - $12 \mu 1$

Solvent system - Toluene: Ethyl Acetate (9:1)

Table 4: Rf value of sample of Chakramarda taila

\begin{tabular}{|c|c|c|}
\hline 254nm & 366nm & Post derivatisation \\
\hline- & - & 0.04 (D. purple) \\
\hline 0.09 (Green) & 0.09 (FD. brown) & - \\
\hline 0.20 (Green) & 0.20 (FL. brown) & - \\
\hline 0.25 (Green) & 0.25 (D. green) & - \\
\hline 0.33 (Green) & 0.33 (D. green) & 0.33 (D. purple) \\
\hline- & - & 0.42 (D. purple) \\
\hline 0.45 (D. green) & 0.45 (F. blue) & - \\
\hline- & - & 0.47 (L. purple) \\
\hline- & 0.49 (FD. brown) & - \\
\hline 0.56 (Green) & - & 0.56 (D. purple) \\
\hline- & - & 0.62 (L. purple) \\
\hline 0.67 (Green) & - & 0.67 (L. purple) \\
\hline- & 0.78 (Yellow) & - \\
\hline 0.80 (D. green) & - & 0.80 (D. Yellow) \\
\hline 0.89 (Green) & - & 0.89 (D. purple) \\
\hline
\end{tabular}




\section{DISCUSSION}

Aim of the analysis is to check the quality of Chakramarda taila and to standardize the formulation. The formulation Chakramarda (Cassia tora Linn) was found to be greenish in color, acrid in taste and had characteristic odour. Tila taila which was clear and pale yellow had turned green due to Chakramarda beeja (seeds) getting paka (incorporated) in it and the acid value of tila taila (Sesamum indicum) is 1.04 which indicates that the oil is not hydrolyzed and it is neutral oil. Refractive index indicates density of sample compared to air and liquid media; the value for Chakramarda taila was found to be 1.47032 , this value is similar to that of tila taila (1.4719) which indicates clearly that finished oil has tila taila base. The specific gravity of Chakramarda taila was found to be 0.9385 which is higher than tila taila $(0.83)$ as specific gravity indicates the presence of solute (Chakramarda seed extract) in the solvent (tila taila) by this it is understood the oil bears the active principles of the Chakramarda seeds in it. Viscosity of Chakramarda taila (58.08) is higher than tila taila (41.14) which indicates that the Chakramarda taila has long duration of action on the body compared to tila taila and intern helps in better absorption into skin. The acid value indicates the presence of free fatty acids in the oil which are responsible for rancidity of the compounds; acid value of Chakramarda taila is noted as 1.04 indicates that it has not undergone hydrolysis to release $\mathrm{FFA}^{7}$. The iodine value indicates the degree of unsaturation of oil and presence of oxidized particles in the oil, the iodine value of Chakramarda taila was found to be 10.73 indicates it is a saturated fatty acid ${ }^{8}$. The Iodine value is lesser than tila taila indicates it has undergone a process called hydrogenation, so it has increased oxidative stability and longer shelf life which might be due to reaction catalyzed by temperature and nature of compounds present in Chakramarda beeja. The Saponification value of Chakramarda taila (oil) is found to be 162.30. The Saponification value indicates the average molecular weight/ chain of fatty acids present. Longer the chains fatty acids have low saponification value and the shorter chain fatty acids have high saponification value ${ }^{9}$ and faster rate of absorption than longer chain fatty acids. Increased saponification value shows that Chakramarda taila has surfactant property and it can be best used as external preparation. Unsaponifiable matter of Chakramarda (Cassia tora Linn) is 1.82 is more than tila taila (1.44) which indicates the presence of non-fatty ${ }^{10}$ matter of Chakramarda beeja in the Chakramarda taila. The $4 \mu \mathrm{l}, 8 \mu \mathrm{l}$ and $12 \mu \mathrm{l}$ were applied using CAMAG Linomat applicator, separation was obtained using toluene: ethyl acetate (9: 1) as mobile phase on silica gel. The Rf values were determined from the photo-documentation performed using CAMAG photo documentation cabinet and the plates were scanned under 254 $\mathrm{nm}, 366 \mathrm{~nm}$ and after derivatisation using CAMAG Scanner. The HPTLC of Chakramarda taila shows $15 \mathrm{Rf}$ values out of which 6 peaks of $\mathrm{Rf}$ values resembles to that of Chakramarda seeds which also indicate the shift of active constituents of Chakramarda seeds into the media.

\section{CONLUSION}

Chakramarda taila is an anuboota yoga, prepared based on the samanya taila paka vidhi in Sarangadhara samhita. The Chakramarda taila has found to possess high saponification value, high viscosity than tila taila which helps in longer duration of action which facilitates better absorption into the skin. Hence the Chakramarda taila has superior healing power with the advantage of base tila taila. The Analytical results with HPTLC finger prints may be considered as tools for manufacturers in developing standards for Chakramarda taila.

\section{REFERENCES}

1. Jgyanendrapandey, Dravyaguna vijnana, Part -III, 3rd ed. Varanasi, Chowkhamba krishnadas Academy; 2005.p.621633.

2. Gupta A. K, Neeraj tendon madhu sharma, quality standards of Indian medicinal plants, vol 06, 2008, Medicinal plants units, Indian council of medical research, Ansari nagar, New Delhi; 2003. p.267

3. Srikanth murthy, Sarangadhara samhita, $2^{\text {nd }}$ edition, Chowkhamba sansthana, Varanasi.p.348

4. Shobha G. Hiremath, A text book of Bhaisajya kalpana, IBH Prakashana, $3^{\text {rd }}$ edition, 2006, Bangalore, p.243.

5. Sastry J L N, DravyagunaVignana, Vol 11, Chaukhamba sanskrita samsthana, Varanasi 2012, P 90.

6. Dept. of AYUSH, Ministry of Health and Family Welfare, Govt. of India. The Ayurvedic Pharmacopoeia of India. $1^{\text {st }}$ ed., Part I, Vol VI. New Delhi: 2008; 233- 291

7. Patil Sahadeo Et Al. phytochemical and Chromatographic Fingerprint Studies on Chloroformic Extracts of Cassia tora L. International Journal of Drug Development and Research, 2014.p431-437

8. Gupta A.K, Neeraj Tandon Madhu Sharma, Quality standards of Indian medicinal plants, volume 06, medicinal plants units, Indian council of medical research New Delhi, 2008.p.422-331

9. Nageswar Rao V et.al Standardisation of Ksheerabala Taila Ancient Science of life, Vol No XVI I July 1996, Page 2125 .

10. Fasina O.O. and Colley Z. International Journal of Food Properties, 2008.p738-746

\section{Cite this article as:}

Anoma Geethani Samarawickrama et al. Chakramarda taila preparation and physico-chemical evaluation. Int. J. Res. Ayurveda Pharm. 2017;8(2):37-39 http://dx.doi.org/10.7897/ $2277-4343.08259$ every effort has been taken to verify the accuracy of the content published in our Journal. IJRAP cannot accept any responsibility or liability for the site content and articles published. The views expressed in articles by our contributing authors are not necessarily those of IJRAP editor or editorial board members. 